\author{
S.K. Kondybayeva ${ }^{1 *}$ (D), G.K. Sadykhanova ${ }^{1}{ }^{10}$, \\ Katarzyna Czerewacz-Filipowicz ${ }^{2}$ id Li Zengrong $^{3}$ \\ ${ }^{1}$ Al-Farabi Kazakh National University, Kazakhstan, Almaty \\ ${ }^{2}$ Bialystok University of Technology, Poland, Bialystok \\ *e-mail: saltanat.kondybaeva@kaznu.kz
}

\title{
THE ROLE OF FOREIGN ECONOMIC RELATIONS OF CHINA ON THE MODERN STAGE AND ITS IMPACT ON KAZAKHSTAN
}

The article is dedicated for analyses cooperation of China with world economy, because as statistics shows PRC has powerful position. In the article, important historical periods were analyzed, as these historical moments had significant influence on China's economy formation after World War II. Nowadays, the growth of the global economy growing fast. For PRC one of the main features of economic growth is the foreign economic activity. In this regard, the cooperation with overseas countries and neighbor countries is the most sufficient task. Partnership between countries, especially in the trade form are effective for both sides, the reason is that countries have opportunities for rising economies. The model of acting foreign economic relations for China is economic zones. Such zones attract for partnership as create favorable conditions between countries. PRC's economic zones concentrated on the territories with industrial structures and these areas are integrated with international relations. As history of Silk way shows, China is a country with rich experience in trading and nowadays world recognize PRC as a power in the world. This article analyzes the foreign economic activity of China. The article describes international relations as a crucial part of the transformation of the national economic system. The work considers literature review of the formation of the worldwide division of labor from the side of theory and methodology. On an example of China explains the development of the national economy with an excess of one of the factors. The article analysis a regression model of influence economic relationships between Kazakhstani and Chinese companies within in the context of the project "One Belt - One Way".

Key words: government policy, international relations, trade, regression model.

$$
\begin{gathered}
\text { С.К. Кондыбаева }{ }^{1 *}, \text { Г.А. Садыханова }{ }^{1} \text { Ч.Ф. Катаржина }{ }^{2}, \text { Цзэнжун Ли } \\
\text { 'Әл-Фараби атындағы Қазақ ұлттық университеті, Қазақстан, Алматы қ. } \\
{ }^{2} \text { Белосток технологиялық университеті, Польша, Белосток қ., } \\
\text { *e-mail: saltanat.kondybaeva@kaznu.kz }
\end{gathered}
$$

\section{Қазіргі кезеңдегі Қытайдың сыртқы экономикалық қатынастарының рөлі және оның Қазақстанға әсері}

Мақалада Қытайдың қазіргі әлемдік экономикадағы орны мен рөлі талданады, өйткені бұл ел тұрақты ұстанымға ие. Жұмыста Қытайдың Екінші дүниежүзілік соғыстан кейінгі экономикалық негізі мен модернизациясымен тығыз байланысты маңызды тарихи кезеңдер талданады. Экономикалық реформаларды бастау, бәсекеге қабілетті экономикалық жүйені құру ҚХР үкіметі үшін басты міндет болды. Соңғы жылдары әлемдік экономика қарқынды дамуда. Бұл міндеттің маңызды бағыты басқа мемлекеттермен сыртқы экономикалық байланыстар болды. Мұндай ынтымақтастық екі жаққа да тиімді, өйткені елдерге өз экономикаларын дамытуға мүмкіндік берді. Қытай шетелдік серіктестерге қолайлы жағдай жасайтын экономикалық аймақтар құрды. Экономикалық аймақтар негізінен әлемдік экономикаға интеграцияланған өндірістік құрылымдардың аумақтарынан тұрды. Сыртқы экономикалық қызмет барған сайын экономикалық дамудың негізгі факторларының біріне айналуда. Қытай әлемдегі ежелгі сауда державаларының бірі. Бұл мақалада Қытайдың сыртқы экономикалық қызметі талданады. Мақалада халықаралық қатынастар ұлттық экономикалық жүйені қайта құрудың шешуші бөлігі ретінде сипатталған. Жұмыста халықаралық еңбек бөлінісінің қалыптасуына теория мен әдіснамалық тұрғыдан шолу қарастырылған. Қытай мысалында ұлттық экономиканың дамуын факторлардың бірінен асып кетуімен түсіндіреді. Мақалада «Бір белдеу - бір жол» жобасының аясында Қазақстан мен Қытай компаниялары арасындағы экономикалық қатынастарға әсер етудің регрессиялық моделі талданады.

Түйін сөздер: мемлекеттік саясат, халықаралық қатынастар, сауда, регрессиялық модель. 


\author{
С.К. Кондыбаева ${ }^{1 *}$, Г.А. Садыханова ${ }^{1}$, Ч.Ф. Катаржина ${ }^{2}$, Цзэнжун Ли \\ ${ }^{1}$ Казахский национальный университет им. аль-Фараби, Казахстан, г. Алматы \\ ${ }^{2}$ Белостокский технологический университет, Польша, г. Белосток \\ *e-mail: saltanat.kondybaeva@kaznu.kz
}

\title{
Роль внешнеэкономических связей Китая на современном этапе и его влияние на Казахстан
}

\begin{abstract}
В статье анализируются место и роль Китая в современной мировой экономике, поскольку эта страна занимает все более твердые позиции, а также анализируются важные исторические периоды, тесно связанные со становлением и модернизацией экономики Китая после Второй мировой войны. Начало экономических реформ, создание конкурентоспособной экономической системы было главной задачей правительства КНР. Важнейшим направлением этой задачи были внешнеэкономические связи с другими государствами. Такое сотрудничество эффективно для обеих сторон, поскольку позволяет странам развивать собственную экономику. Китай построил экономические зоны, которые создали благоприятные условия для иностранных партнеров. Экономические зоны в основном состояли из территорий промышленных структур, интегрированных в мировую экономику. В последние годы развитие мировой экономики стремительно растет. Внешнеэкономическая деятельность все больше становится одним из основных факторов экономического развития. Китай - одна из старейших торговых держав мира. В статье исследуются внешнеэкономическая деятельность Китая, при этом международные отношения рассматриваются как важнейшая часть трансформации национальной экономической системы. В работе рассматривается литературный обзор становления международного разделения труда со стороны теории и методологии. На примере Китая объясняется развитие национальной экономики с превышением одного из факторов. В статье анализируется регрессионная модель влияния экономических отношений между казахстанскими и китайскими компаниями в рамках проекта «Один пояс - один путь».

Ключевые слова: государственная политика, международные отношения, торговля, регрессионная модель.
\end{abstract}

\section{Introduction}

Beginning the economic reorganizations, the construction a competitive economic structure was one of the important mission for the Chinese authority. The overseas economic cooperations with other neighbor countries were the greatest and vital course of this mission. Partnership between countries, especially in the trade form are effective for both sides, the reason is that countries have opportunities for rising economies. The model of acting foreign economic relations for China is economic zones. Such zones attract for partnership as create favorable conditions between countries. PRC's economic zones concentrated on the territories with industrial structures and these areas are integrated with international relations.

The economic reorganizations has had a progressive consequence. Currently, several states attempt to repeat this practice, because this model of economic development proved values the PRC expected. The inheritance of Western economic scientists' works inspired China, as the impression of the opening the doors of the nationwide to the whole world was engaged from the works of classical and neoclassical economic concepts. The first project of economic zone by PRC was the "Shannon" in Iceland. This project of economic zone afforded to attract the interests of investors' funds. The building of entities in the territory of the PRC was probable because of growing export sizes, taxes, and customs duties.

The PRC had closing economic structure for the period of the overall integration of countrywide economic movement with the overseas countries' economies. China's government accepted a totally new reform in the late 1970s. The expansion of a policy aimed at the inclusive expansion of overseas economic relationships was a significant and essential share of the direction of deep economic reorganizations. The course directed the steady integration of China's countrywide economy to the world economy. This direction of the strategy was to growth the possible of economic, research and technical relations with overseas states. The goal involved the operational building of the economy, the strengthening of production process, the overview of active procedures of organization and management, and the development of municipal relationships in PRC.

The PRC's overseas economic strategy has different ways. From side to side, the modification of guidelines, it is possible to study detailed native circumstances more completely and to deliver particular tackles for resolving convinced priorities.

\section{Literature Review}

The working of the worldwide trade structure, monetary and credit procedures, and the establishment 
of services are the basics and essences of the world economic structure. The principal suggests around the growth of the economy we can realize in the papers of classical economists. The member of classical school A. Smith (Smith, 1904) was the leading economist, who presented thought around an examination of the organization of the worldwide division of labor. According to the scientific literature, his method is identified as the principle of absolute advantage.

The Swedish economists Eli Heckscher and Bertil Ohlin generated a natural resource abundance concept the end of the nineteenth century and the beginning of the twenties century. From side to side, this novel theory tried to clarify the details and instrument for the worldwide trade in manufacturing outputs. In 1919, E. Heckscher assessed trade practices and expressed the key requirements of the natural resource abundance concept. In the 20 s and $30 \mathrm{~s}$, Bertil Ohlin widespread and advanced these requirements (Ohlin, 1933).

Agreeing to the Heckscher-Ohlin idea, nations transfer those properties, which they can maximum resourcefully and abundantly produce. The three main factors labour, capital and land are recognized to the classification in economic theory. Nevertheless, the Heckscher-Ohlin concept is two-factor that relates only two factors labor power and capital investment. Therefore, a nation has in abundance certain of the two factors. Certain properties are labor demanding, whereas others are capital demanding. Therefore, in a state, which surplus of labor factors and lack of capital factors, the labor factor will be comparatively inexpensive, and capital factor will be costly. Furthermore, vice versa, a state with limited labor assets and there is appropriate capital, labor will be expensive and capital cheap. Nations will select exporting or importing depending on present assets they have. The economies will export outputs, which are comparatively inexpensive to produce, by more of the "cheap factor of production." This is precise significant to include the influence of redundancy of one of the factors on the expansion of the economic movement. T. M. Rybczynski (Rybczynski, 1955) is recognized as an economist examined this problem. T. M. Rybczynski made a statement constructed on the consequences of his papers. The statement is Rybczynski theorem. According to the theorem, a rise in the supply of one of the factors of production, all the factors remain equal, will cause a rise in the production produced with the active use of this factor and to a reduction in the output of other outputs.

The applied meaning of the theorem can be shown through the experience of the PRC's economic expansion. It proves that the high proportion of the "labor" force in the economy needs the fascination of the extra economic features "capital" and "land".

The next theory is "product life cycle", which is the most widely held theory of the neotechnological course. R. Vernon (Vernon, 1966) created this theory in 1966 and interested practically all economists. The cause such attractiveness was that it more precisely describes the existent condition of the worldwide division of labour in the current time. Consistent with this theory, every innovative output has phases. A phase includes the periods of application, development, maturity and ageing.

In agreement with this theory, economies' concentration and exporting on the same good, nevertheless at not the same periods of maturity.

An instance is the state's growth of the AsiaPacific region. These countries have a continuous process of the fruitful way of definite stages of economic growth by high-industrial States, new industrial countries (NIS) and ASEAN countries (Czerewacz-Filipowicz and Konopelko, 2016). For instance, ASEAN states in the sphere of technology nowadays are doing the same as NIS did in the recent past and embark on the identical way of "quality of specialization."

The concepts study the growth process of IER (Czerewacz-Filipowicz and Konopelko, 2016). As we mentioned steadily, the IER academics involved an increasing amount of factors included in the formation of a countrywide economic structure. Study of the relationship of these factors illustrates the likelihood of expansion of the countrywide economy if it is joined into the world system.

As said by Yuan Peng, Director of the Institute of the USA of the Chinese Academy of Modern International Relations, the PRC is at the current on a great period of development. In conjunction with other countries, in the condition of self-determining and shared renovation. The PRC should be defined as an important dynamic force for transformations in the frame of international system that defines the place of China in the modern world. The PRC nowadays reproduces four not the same units, and so-called "four in one" (Peng, 2014):

- Developing nation;

- Growing power;

- Worldwide power;

- Quasi - superpower.

In the up-to-date world, well-known are four types of states - superpowers, strong, medium, and weak (Ling, 2014).

The first set of superpowers contains only one nation - the USA. By way of U.S. strategy, the concept of realism, along with the geopolitical and 
sea power of Mahan theories are being realized. The American policy is worldwide, the USA's position in defining the guidelines of the game in the world is leading, besides is the author of basic concepts of international relationships.

The next group of robust countries consist of Great Britain, France, Germany, Japan, China, Russia, India, Brazil, etc. These states are involved in worldwide matters, guiding key exertions to their areas. The set of strong states practice the value of "balance of power" that attends as the determination of concluding coalitions as a path to counter the PRC to USA.

The third set of states contains "medium countries". In the outline of global political architectonics, these states are the member of the middle class, together with the countries of Northern and Eastern Europe, the Middle East, Central and Southeast Asia, Africa and Latin America. Not every of these states has the measurements to have a self-governing influence on worldwide policy as well as on local matters. Two-sided and boundary issues are the key difficulties addressed by the states of this set (Czerewacz-Filipowicz, 2019). Unions of medium-sized states involve of more than 10 states, only in this circumstance the group is actual.

The fourth set of states contains small and very small "weising" states, like Luxembourg and Andorra in Europe, Bhutan and Brunei in Asia. Intended for the most part, states have its place in this set are external viewers in the application of global policy. These states be able to join great powers.

According to Wang Honggang, an expert at the Chinese Academy of Contemporary International Relations, the part of USA in PRC has been overvalued ever since the 2008 worldwide economic crisis (Honggang, 2014). The PRC has expressed its place by means of respect to the United States and China did not consider the America as the single global arbitrator.

\section{Materials and methods}

\section{Foreign economic relations of China}

The processes of the worldwide division of labour and internationalization of manufacture, the speeding up of global research and technological development have caused China to have an objective need to pursue a policy of foreign economic openness in the interests of its own development at the step of changeover to a market economy.

The 3rd Plenary Session of the Central Committee of the Communist Party of PRC of the 11th convocation (December 1978), proclaiming "openness" as a long-term policy, a necessary condition and an essential prerequisite for the modernization of the economy (Liu and etc., 2020). This provision was included in the manuscript of the new-fangled Constitution of China of 1982.

Having defined a general course for the expansion of external relations and having taken the first steps towards its implementation, the PRC has gone very consistently. The ways: the establishment of a free economic zone in the south-east of the country in 1980, the opening of port cities for foreign capital along the coastline in 1984, the creation of special areas of technical and economic development in 1985. All these decisions gave opportunity to create a base for attracting foreign capital and, most importantly, the latest technologies (Czerewacz-Filipowicz, 2019).

For the duration of the years of reorganization, the PRC's integration to international economic relationships has enhanced markedly, particularly in the Asia-Pacific area. The part of the overseas economic issue in the nationwide economy has improved. The normal yearly growing rate of overseas trade through the first half of the 1990s (19.5\%) was well ahead of the general economic development. In 2002 , overseas trade income raised to $\$ 510$ billion, and in 2018 amounted to $\$ 4.5$ trillion (Lalwani and Chakraborty, 2020). The amount of trade associates of China raised meaningfully in the 1990s: since 173 in 1990 to 227 in 2002.

Consistent with formal statistics, three hundred biggest transnational corporations (TNCs) in the world decided to invest in China. Twenty major companies of Japan, around 19 decided to choose Chinese market as a new place. Surrounded by European TNCs Germany's ten major companies, nine invested in PRC. Even, among the twenty biggest businesses in the USA and South Korea, sixteen decided to invest in China.

At the beginning of the 1980s, TNCs invested numerous million dollars in single capacity in PRC. Nowadays investments into single item in PRC on ordinary raised to ten billion dollars, items with the amount over 100 billion dollars give the impression more and more. The plan of the German company BASF and the petrochemical plant Yangtze (China) delivers on behalf of the attraction of investment from foreign countries of 3 billion dollars.

Exports raised by $7.1 \%$ in yearly terms to 16.42 trillion Yuan, imports - by $12.9 \%$ to 14.09 trillion Yuan in 2018. The trade excess was therefore concentrated by $18.3 \%$ to 2.33 trillion Yuan.

Furthermore, the whole size of imports and exports in the outline of conservative trade presented a growth of $12.5 \%$, amounting to 17.64 trillion Yuan, otherwise $57.8 \%$ of the nation's overseas trade income, which is 1.4 proportion points greater than the level of 2017. 
The PRC's trade income with the European countries, United states and ASEAN nations raised by $7.9 \%, 5.7 \%$ and $11.2 \%$, correspondingly. They accounted for $41.2 \%$ of the nation's full overseas trade.

At a rate overhead normal, trade income with states along the "Belt and Way" improved, which amounted to 8.37 trillion Yuan that is 13.3 percent greater than in 2018 (Jaros and Tan, 2020).

In spite of a comparatively little portion of global trade of $2.9 \%$ in 1995 , PRC in several years of reorganization has become a great world trading power, which shows ranking the 11th place in the global in overseas trade and export in the 1990s, taken place in 1978 only in 32. In 2001, the PRC was amongst the highest trading powers in the world (Yang and Liang, 2019). China's important part in the global economy is also because of the extra-fast development of countrywide production, the interests of foreign capital in local market, the aggregate size of gross national product, which is lower in actual positions only to the USA and Japan.

Analysis of economic relationships of Kazakhstan with Chinese companies in the context of the project "One Belt - One Way"

By 2015, in connection with the application of the project "One Belt - One Way," direct Chinese investments in the Republic of Kazakhstan achieved to $\$ 23.6$ billion. In the frame of the Chinese FDI, Kazakhstan has the $3^{\text {rd }}$ ranks in the worldwide after Australia and the USA (Maochun, etc., 2015; Official website of Ministry of national economy of the RK Statistics Committee). The key investment assignments of Chinese businesses in the nation are connected to the fuel complex, primarily oil and gas manufacture (greater than 25 percent of Kazakhstani oil is made by Chinese corporations), the building and operation of gas and oil pipelines. Of the whole FDI, \$ 21.2 billion of investment (is $90 \%$ ) was directed in fuel and energy complex and pipelines, with $\$ 17.2$ billion in the taking out and processing of energy resources and around $\$ 4$ billion in the transference of oil and gas. The foremost Chinese investor in Kazakhstan is the biggest Chinese oil and gas corporation, China National Petroleum Corporation (CNPC).

Presently, further 2,600 Chinese companies function in Kazakhstan, and the amount is continuously growing (Official website of Ministry of national economy of the RK Statistics Committee).

In this scientific work, the authors are guided by the theoretical method of research - comparative analysis of scientific literature, articles, interview records and conferences on the issue, processing and synthesis of obtained data, analysis of economic and diplomatic treaties and agreements between China and Kazakhstan, and use the method of building regression dependence.

In order to determine the level of influence of Chinese companies on the economy of Kazakhstan, we will build a model of panel regression, reflecting dependence:

Kazakhstan's GDP (in billions of US dollars) during the period from 2014 to 2018 from such indicators as total assets of Chinese companies (Total Assets - TA - in billions of dollars), Total liabilities of Chinese companies (Total Liabilities - TL - in billions of dollars), tax payments (Taxes, billions of dollars), return on equity of Chinese companies (ROE,\%), return on assets of Chinese companies (ROA,\%), project profit (Profit, billion dollars), the number of employees - citizens of Kazakhstan in the analyzed Chinese companies (KZ, thousand people), the number of workers - citizens of China in the analyzed Chinese companies (China, thousand people), investment volume (Investments - Inv, \% of Kazakhstan's GDP), import volume (Import, billion dollars), export volume (Export, billion dollars), Tenge to US dollar exchange rate (Exchange rate - EX).

The model for studying the dependence of Kazakhstan's GDP in the period from 2014 to 2018 is as follows:

$$
\mathrm{GDP}_{t}=\beta_{0}+\beta_{1} \mathrm{TA}_{\mathrm{t}}+\beta_{2} \mathrm{TL}_{\mathrm{t}}+\beta_{3} \operatorname{Tax}_{\mathrm{t}}+\beta_{4} \mathrm{ROE}_{\mathrm{t}}+\beta_{5} \mathrm{ROA}_{\mathrm{t}}+\beta_{6} \text { Profit }_{\mathrm{t}}+\beta_{7} \mathrm{KZ}_{\mathrm{t}}+\beta_{4} \mathrm{CH}_{\mathrm{t}}+\beta_{4} \mathrm{Inv}_{\mathrm{t}}+\zeta
$$

where, GPD - dependent variable,

TA - total assets of Chinese companies (Total Assets - TA),

TL - total liabilities of Chinese companies (Total Liabilities - TL),

TAX - tax payments (Taxes), (ROE),

ROE - return on equity of Chinese companies

ROA - return on assets of Chinese companies (ROA),
Profit - project profit (Profit),

$\mathrm{KZ}$ - the number of employees - citizens of Kazakhstan in the analyzed Chinese companies (KZ),

$\mathrm{CH}$ - the number of workers - citizens of China in the analyzed Chinese companies (China),

Inv - investment volume (Investments),

Import - import volume,

Export - export volume,

ER (exchange rate) - exchange rate and $\zeta$ - error. 
The following hypotheses are put forward as part of the study:

$\mathbf{H}_{1}$ : The GDP of Kazakhstan in the context of the plan "One Belt, One Way" is positively influenced by such indicators as total assets of Chinese companies (TA), tax payments (Taxes), return on equity of Chinese companies (ROE), the number of employees - citizens of Kazakhstan in the analyzed Chinese companies (KZ), the number of workers citizens of China in the analyzed Chinese companies
(China), investment volume (Inv), import volume (Import).

$\mathbf{H}_{2}$ : The GDP of Kazakhstan in the context of the plan "One Belt, One Way" is negatively influenced by such indicators as Total liabilities of Chinese companies (TL), return on assets of Chinese companies (ROA), project profit (Profit), export volume (Export) and exchange rate (ER). Let us construct a matrix of observed values of $t$-statistics for all coefficients $r_{i j}$ (table) for $\alpha=0,01=\alpha=0,1=2,578764163$.

Table 1 - Matrix of observed t-statistic values $(\alpha=0,01=\alpha=0,1=2,578764163)$

\begin{tabular}{|c|c|c|c|c|c|c|c|c|c|c|c|c|c|}
\hline & $\begin{array}{c}\text { GDP } \\
\text { Kazakhstan } \\
\text { (Y), billion } \\
\text { dollars }\end{array}$ & $\begin{array}{c}\text { TA, billion } \\
\text { dollars }\end{array}$ & \begin{tabular}{|c|} 
TL, \\
billion \\
dollars
\end{tabular} & $\begin{array}{l}\text { Taxes, } \\
\text { billion } \\
\text { dollars }\end{array}$ & ROE, \% & ROA, $\%$ & $\begin{array}{l}\text { Profit, } \\
\text { billion } \\
\text { dollars }\end{array}$ & $\begin{array}{c}\mathrm{KZ} \text {, the } \\
\text { number of } \\
\text { employees }\end{array}$ & $\begin{array}{l}\text { Chin, the } \\
\text { number of } \\
\text { employees }\end{array}$ & $\begin{array}{c}\text { Invest, } \\
\% \text { from } \\
\text { GDP of } \\
\text { Kazakhstan }\end{array}$ & $\begin{array}{l}\text { Import, } \\
\text { billion } \\
\text { dollars }\end{array}$ & $\begin{array}{l}\text { Export, } \\
\text { billion } \\
\text { dollars }\end{array}$ & $\begin{array}{c}\text { ER- Tenge } \\
\text { to US dollar } \\
\text { exchange } \\
\text { rate }\end{array}$ \\
\hline $\begin{array}{c}\text { GDP } \\
\text { Kazakhstan } \\
(\mathrm{Y}) \text {, billion } \\
\text { dollars }\end{array}$ & & 0,407 & $-1,596$ & 1,645 & $-1,507$ & $-2,192$ & $-0,787$ & 0,847 & $-4,573$ & 1,293 & $-0,734$ & 3,575 & $-83,406$ \\
\hline $\begin{array}{c}\text { TA, billion } \\
\text { dollars }\end{array}$ & 0,407 & & 60,354 & 22,385 & $-6,392$ & $-6,217$ & 19,142 & 54,566 & 12,190 & 10,047 & 1,725 & $-2,658$ & 0,728 \\
\hline $\begin{array}{c}\text { TL, billion } \\
\text { dollars }\end{array}$ & $-1,596$ & 60,354 & & 25,750 & 2,443 & 0,650 & 21,994 & 33,901 & 34,070 & 7,976 & 1,896 & $-2,483$ & 2,140 \\
\hline $\begin{array}{l}\text { Taxes, } \\
\text { billion } \\
\text { dollars. }\end{array}$ & 1,645 & 22,385 & 25,750 & & 11,567 & 1,046 & 24,588 & 13,091 & 12,993 & 17,272 & 1,529 & 0,011 & $-0,912$ \\
\hline ROE, \% & $-1,507$ & $-6,392$ & 2,443 & 11,567 & & 110,827 & 39,822 & $-10,233$ & 14,271 & 33,378 & $-12,229$ & $-10,547$ & 0,870 \\
\hline ROA, \% & $-2,192$ & $-6,217$ & 0,650 & 1,046 & 110,827 & & 37,395 & $-10,044$ & 12,190 & 32,596 & $-14,430$ & $-12,702$ & 1,403 \\
\hline $\begin{array}{l}\text { Profit, } \\
\text { billion } \\
\text { dollars }\end{array}$ & $-0,787$ & 19,142 & 21,994 & 24,588 & 39,822 & 37,395 & & 5,717 & 17,983 & 71,514 & $-8,634$ & $-10,345$ & 0,776 \\
\hline $\mathrm{KZ}$ & 0,847 & 54,566 & 33,901 & 13,091 & $-10,233$ & $-10,044$ & 5,717 & & 6,415 & $-4,015$ & 11,486 & 7,433 & $-0,122$ \\
\hline China & $-4,573$ & 12,190 & 34,070 & 12,993 & 14,271 & 12,190 & 17,983 & 6,415 & & 2,374 & 2,386 & $-0,105$ & 4,391 \\
\hline Invest, $\%$ & 1,293 & 10,047 & 7,976 & 17,272 & 33,378 & 32,596 & 71,514 & $-4,015$ & 2,374 & & $-17,831$ & $-13,270$ & $-1,080$ \\
\hline $\begin{array}{l}\text { Import, } \\
\text { billion } \\
\text { dollars }\end{array}$ & $-0,734$ & 1,725 & 1,896 & 1,529 & $-12,229$ & $-14,430$ & $-8,634$ & 11,486 & 2,386 & $-17,831$ & & 16,208 & 0,593 \\
\hline $\begin{array}{l}\text { Export, } \\
\text { billion } \\
\text { dollars }\end{array}$ & 3,575 & $-2,658$ & $-2,483$ & 0,011 & $-10,547$ & $-12,702$ & $-10,345$ & 7,433 & $-0,105$ & $-13,270$ & 16,208 & & $-7,083$ \\
\hline ER & $-83,406$ & 0,728 & 2,140 & $-0,912$ & 0,870 & 1,403 & 0,776 & $-0,122$ & 4,391 & $-1,080$ & 0,593 & $-7,083$ & \\
\hline
\end{tabular}

Note - compiled by the authors on the Excel. Statistical data source (Official website of Ministry of national economy of the RK Statistics Committee).

By the results presented in table 1 , the observed value of t-statistics is more than critical $t_{c r}=2.578764163$ on the module for the pair coefficients of correlation highlighted in bold type in the above-stated table. Consequently, the hypothesis that these coefficients are equal to zero is rejected 
with a probability of error of 0.01 and 0.1 , i.e. corresponding coefficients are significant.

For the remaining coefficients, the observed value of the t-statistic is less than the critical value modulo, hence the $\mathrm{H}_{0}$ hypothesis is not rejected, i.e. the coefficients not shown in bold are insignificant.

We construct a matrix of observed values of t-statistics for all coefficients $r_{i j}$ (table) for $\alpha=0.05$ $=1.961379532$.

Table 2 - Matrix of observed t-statistic values $(\alpha=0,05=1,961379532)$

\begin{tabular}{|c|c|c|c|c|c|c|c|c|c|c|c|c|c|}
\hline & $\begin{array}{c}\text { GDP } \\
\text { Kazakhstan } \\
\text { (Y), billion } \\
\text { doll. }\end{array}$ & $\begin{array}{c}\text { TA, } \\
\text { billion } \\
\text { dollars }\end{array}$ & $\begin{array}{c}\text { TL, } \\
\text { billion } \\
\text { dollars }\end{array}$ & $\begin{array}{l}\text { Taxes, } \\
\text { billion } \\
\text { dollars }\end{array}$ & $\begin{array}{c}\mathrm{ROE}, \\
\%\end{array}$ & $\begin{array}{c}\mathrm{ROA}, \\
\%\end{array}$ & $\begin{array}{l}\text { Profit, } \\
\text { billion } \\
\text { dollars }\end{array}$ & $\begin{array}{c}\mathrm{KZ} \text {, the } \\
\text { number of } \\
\text { employees }\end{array}$ & $\begin{array}{l}\text { Chin, the } \\
\text { number of } \\
\text { employees }\end{array}$ & $\begin{array}{c}\text { Invest, } \\
\% \text { from } \\
\text { GDP of } \\
\text { Kazakhstan }\end{array}$ & $\begin{array}{l}\text { Import, } \\
\text { billion } \\
\text { dollars }\end{array}$ & $\begin{array}{l}\text { Export, } \\
\text { billion } \\
\text { dollars }\end{array}$ & $\begin{array}{c}\text { ER- } \\
\text { Tenge to } \\
\text { US dollar } \\
\text { exchange } \\
\text { rate }\end{array}$ \\
\hline $\begin{array}{c}\text { GDP } \\
\text { Kazakhstan } \\
\text { (Y), billion } \\
\text { dollars }\end{array}$ & & 0,407 & $-1,596$ & 1,645 & $-1,507$ & $-2,192$ & $-0,787$ & 0,847 & $-4,573$ & 1,293 & $-0,734$ & 3,575 & $-83,406$ \\
\hline TA & 0,407 & & 60,354 & 22,385 & $-6,392$ & $-6,217$ & 19,142 & 54,566 & 12,190 & 10,047 & 1,725 & $-2,658$ & 0,728 \\
\hline TL & $-1,596$ & 60,354 & & 25,750 & 2,443 & 0,650 & 21,994 & 33,901 & 34,070 & 7,976 & 1,896 & $-2,483$ & 2,140 \\
\hline Taxes & 1,645 & 22,385 & 25,750 & & 11,567 & 1,046 & 24,588 & 13,091 & 12,993 & 17,272 & 1,529 & 0,011 & $-0,912$ \\
\hline ROE, \% & $-1,507$ & $-6,392$ & 2,443 & 11,567 & & 110,827 & 39,822 & $-10,233$ & 14,271 & 33,378 & $-12,229$ & $-10,547$ & 0,870 \\
\hline ROA, \% & $-2,192$ & $-6,217$ & 0,650 & 1,046 & 110,827 & & 37,395 & $-10,044$ & 12,190 & 32,596 & $-14,430$ & $-12,702$ & 1,403 \\
\hline Profit, & $-0,787$ & 19,142 & 21,994 & 24,588 & 39,822 & 37,395 & & 5,717 & 17,983 & 71,514 & $-8,634$ & $-10,345$ & 0,776 \\
\hline $\mathrm{KZ}$ & 0,847 & 54,566 & 33,901 & 13,091 & $-10,233$ & $-10,044$ & 5,717 & & 6,415 & $-4,015$ & 11,486 & 7,433 & $-0,122$ \\
\hline China & $-4,573$ & 12,190 & 34,070 & 12,993 & 14,271 & 12,190 & 17,983 & 6,415 & & 2,374 & 2,386 & $-0,105$ & 4,391 \\
\hline Invest, $\%$ & 1,293 & 10,047 & 7,976 & 17,272 & 33,378 & 32,596 & 71,514 & $-4,015$ & 2,374 & & $-17,831$ & $-13,270$ & $-1,080$ \\
\hline Import, & $-0,734$ & 1,725 & 1,896 & 1,529 & $-12,229$ & $-14,430$ & $-8,634$ & 11,486 & 2,386 & $-17,831$ & & 16,208 & 0,593 \\
\hline Export, & 3,575 & $-2,658$ & $-2,483$ & 0,011 & $-10,547$ & $-12,702$ & $-10,345$ & 7,433 & $-0,105$ & $-13,270$ & 16,208 & & $-7,083$ \\
\hline ER & $-83,406$ & 0,728 & 2,140 & $-0,912$ & 0,870 & 1,403 & 0,776 & $-0,122$ & 4,391 & $-1,080$ & 0,593 & $-7,083$ & \\
\hline
\end{tabular}

Note - compiled by the authors on the Excel. Statistical data source (Official website of Ministry of national economy of the RK Statistics Committee).

The strongest correlation is observed between TA and TL, as well as Investments and Profit, ER and GDP.

\section{Estimation of regression model parameters}

We will build regression models based on GDP (on three levels of significance 90, 95, 99).
Due to the results of these tables, we can get the beta coefficients in our model. According to the tables, almost all variables have a p-value less than 0.05 , which means that the variables are of great importance.

As a result, the equation is as follows:

$$
\begin{gathered}
\mathrm{GDP}=318,616+\text { 0,286TA-7,198TL+3,053TAX+1,759ROE-4,253ROA-4,289Profit }+0,001 \mathrm{KZ}+ \\
\text { 0,001CH+1,337Inv+0,901Imp-4,404Exp-3,539ER }
\end{gathered}
$$

Thus, in the framework of the "One Belt, One Way" project, indicators such as current assets of Chinese companies $(\mathrm{PV}=0,286)$, TAX $(\mathrm{PV}=$ 3,053), ROE ( $\mathrm{PV}=1.759)$, number of employees
- citizens of Kazakhstan involved in the project implementation ( $\mathrm{PV}=0,001), \mathrm{CH}(\mathrm{PV}=0,001)$, Inv $(\mathrm{PV}=1,337), \operatorname{Imp}(\mathrm{PV}=0,901)$ have positive effects Kazakhstan's GDP. 
The following indicators provide the negative impact on the GDP of Kazakhstan at the level of significance 90 within the project implementation: TL ( $\mathrm{PV}=-7,198)$, ROA ( $\mathrm{PV}=-4,253)$, Profit ( $\mathrm{PV}=-$ 4,289), $\operatorname{Exp}(\mathrm{PV}=-4,404), \mathrm{ER}(\mathrm{PV}=-3.539)$.

\section{Conclusion}

In the framework of openness, the global trade is the one of the factor and reason of the economic progress and expansion of the states. From the time when worldwide relationships create conditions for availably usage a chance to appreciate the benefit of the nationwide economic structure. It is important to high point the role of the government. As shows the history of economic development of China, the new economic reforms have significant effect. China's Government is generating advantageous surroundings for export expansion. The PRC is producing the compulsory portions for assembly inside of the state, which is measured as strategies to protect currency and make an excess in trade (Kondybayeva etc., 2018).

The manufacture processes, scientific research, computerization are fields that requires maximization of efforts. Because focusing to these spheres can lead to economic growth of the nation.
Any country should develop all industries equally and try to avoid the consequences as excessive development of one industry in relation to another, as it can lead to imbalance and crisis in the economy as a whole.

Chinese Government started their policy from of attracting foreign investment. Nowadays, they are focusing on science development and searching ways to attract new technologies to China. Because novelty and innovations are, not only source of science growth, but also conditions for attracting further investment. This applies mainly to direct investment by entrepreneurs, large corporations and TNCs.

After 1991 when Kazakhstan gained independence, political, cultural and economic ties with foreign countries began to develop actively. Especially, relations with China: bilateral trade is rapidly gaining momentum, and areas of cooperation are constantly expanding. The volume of foreign direct investment (FDI) from China to RK also reflects the degree of trade and economic cooperation.

Trade and economic cooperation between Kazakhstan and China are characterized by complementarity. However, these complementary benefits are not fully utilized, and the investment climate needs to be improved.

\section{References}

Czerewacz-Filipowicz, K. (2019) The Eurasian Economic Union as an Element of the Belt and Road Initiative. Comparative Economic Research, vol. 22 -2, pp. 23-37. DOI: 10.2478/cer-2019-0010

Czerewacz-Filipowicz, K., Konopelko, (2016) A. Regional Integration Processes in the Commonwealth of Independent States: Economic and Political Factors. Book. Springer (2016). Pages 348. DOI: 10.1007/978-3-319-47563-9

Honggang, W. (2014) How can the U.S. and China build a "Cooperative partnership". Contemporary International Relations, vol. $21-4$. Source// http://www.cicir.ac.cn/english/ArticleView.aspx?nid=2934

Jaros, K.A., Tan, Y. (2020) Provincial power in a centralizing china: The politics of domestic and international "development space". China Journal, vol. 83 - 1, pp. 79-104. DOI: 10.1086/706256

Kondybayeva, S., Nurgazy, S., Ospanov, S., Mukhamediyev, B., Sadykhanova, G., (2018) Food Market of Kazakhstan: Current State and Innovative development Directions. Proceedings of the 31st International Business Information Management Association Conference, IBIMA 2018: Innovation Management and Education Excellence through Vision 2020, P. 4312-4317.

Lalwani, V., Chakraborty, M. (2020) Aggregate earnings and gross domestic product: International evidence. Applied Economics, vol. 52 - 1, pp. 68-84. DOI: 10.1080/00036846.2019.1640859

Ling, J. (2014) "Silk Roads"- China Marshall Plan. (China Science Center for International Studies) http://www.cnki.com.cn/ Article/CJFDTOTAL-GJWY20150 1008.html

Liu, S., Dong, Z., Ding, C., Wang, T., Zhang, Y. (2020) Do you need cobalt ore? Estimating potential trade relations through link prediction. Resources Policy, vol. 66

Maochun, H., Jibing, Z., Yapeng, Z., Bin, T. (2015) Center of Research in Economic Diplomacy. Journal of Xinjiang Normal University (Edition of Philosophy and Social Sciences), vol.36 - 3. P. 44.

Official website of Ministry of national economy of the RK Statistics Committee/ Official statistics/ Monitoring of the sustainable development goal until 2030. Source: https://stat.gov.kz/official/sustainable_development_goals

Ohlin, B., (1933) Interregional and International Trade, Cambridge, Mass.; Harvard University Press.

Peng, Y. (2014) China's strategic choices. Contemporary International Relations, vol. 20 - 1. pp. 17-32

Rybczynski, T. M. (1955) Factor Endowment and Relative Commodity Prices. Economica, New series, vol.22-88, pp.336-341. DOI: $10.2307 / 2551188$

Smith, A. (1904) An Inquiry into the Nature and Causes of the Wealth of Nations. London: Methuen and Co., Ltd., ed. Edwin Cannan, Fifth edition.

Vernon, R. (1966) International Investment and International Trade in the Product Cycle. The Quarterly Journal of Economics, 2, pp. 190-207. DOI:10.2307/1880689

Yang, Y.E., Liang, W. (2019) Introduction to China's Economic Statecraft: Rising Influences, Mixed Results. Journal of Chinese Political Science, vol. 24 - 3, pp. 381-385. DOI: 10.1007/s11366-019-09614-1 